\title{
Multiple Intellegences of Social Sciences and Linguistics Students Grade X Crossing Biology Interest
}

\section{Multiple Intellegences Peserta Didik Kelas X Peminatan Ilmu Sosial dan Bahasa Lintas Minat Biologi}

\author{
Rahmadhani Fitri ${ }^{1)}$, Ganda Hijrah Selaras ${ }^{1)}$, Rika Andima ${ }^{1)}$, \\ Rizki Rahman Putra ${ }^{1)}$ Resti Fevria ${ }^{1)}$, Indra Hartanto ${ }^{1)}$ \\ 1)Jurusan Biologi, Fakultas Matematika dan IPA, Universitas Negeri Padang \\ Jalan Prof. Dr. Hamka, Air Tawar, Kota Padang, Sumatera Barat, Indonesia Kode Pos 25131 \\ Email: rahmadhanifitr@fmipa.unp.ac.id
}

\begin{abstract}
Multiple intelligences are the development of intelligence of the brain or intelligence quotient (IQ), emotional intelligence or emotional quotient (EQ), and spiritual intelligence or Spiritual Quotient (SQ). The intelligence consists of nine levels of intelligence is known as the Multiple Intelligences (MI) which includes: linguistic intelligence, mathematical-logical intelligence, visual spatial intelligence, physical-kinesthetic intelligence, musical intelligence, interpersonal intelligence, intrapersonal intelligence, naturalist intelligence, and existential lntelligence. This theory shows that there is no human activity that uses only one intelligence, but uses all intelligence that exists in humans. Intelligence is a single talent that students use in situations of solving any problem. Every student has a different intelligence. This is because there are several factors that influence it, namely the hereditary factor, interest factor, formation factor, maturity factor, and freedom factor.This research are descriptive study which aims to reveal the level of MI of social sciences and linguistcs student grade X crossing biology interest at SMAN 1 V Koto KampungDalam. Results of the study, it was faund that the most dominant intelligence in social science students is naturalist intelligence. In the linguistics scienscestudents, the most dominant intelligence is existential intelligence.
\end{abstract}

Keywords: Multiple Intellegences, Biology Interest

\section{PENDAHULUAN}

Salah satu karakteristik penting dari peserta didik yang perlu dipahami oleh guru sebagai pendidik adalah bakat dan kecerdasan individunya. Guru yang tidak memahami kecerdasan dari peserta didik akan memiliki kesulitan dalam memfasilitasi proses pengembangan potensi individu untuk mewujudkan citacitanya. Pada hakikatnya, kecerdasan menduduki tempat yang begitu penting dalam dunia pendidikan, namun seringkali kecerdasan ini dipahami secara parsial oleh 
sebagian guru. Menurut Amir (2013: 2), sesungguhnya setiap anak dilahirkan mempunyai bakat tertentu dan cerdas dengan membawa potensi dan keunikan masing-masing yang memungkinkan mereka untuk menjadi cerdas.

Kecerdasan (intelegensi) merupakan kemampuan dasar yang bersifat umum untuk memperoleh suatu kecakapan dengan berbagai komponen. Menurut Prawira (2012: 138), kecerdasan adalah kemampuan kognitif umum yang dibawa individu sejak lahir. Istilah kecerdasan sering disamakan dengan inteligensi (intelligence) yang berarti menghubungkan atau menyatukan satu sama lain. Kecerdasan merupakan kemampuan untuk melihat suatu pola dan menggambarkan hubungan antara pola di masa lalu dan pengetahuan di masa depan. Kecerdasan anak dapat diperlihatkan lewat banyak cara baik itu melalui kata-kata, angka, musik, gambar, kegiatan fisik (kemampuan motorik) atau lewat cara sosial-emosional. Banyak hasil riset kecerdasan peserta didik menyarankan para orang tua untuk memberi banyak pengalaman dan stimulasi kepada peserta didik. Ahsan (2015: 25), menyampaikan bahwa stimulasi dan sensasi pengalaman yang intens berguna untuk membangkitkan kecerdasan peserta didik yang diterapkan ke dalam konsep teori kecerdasan yang disebutnya "Multiple Intelligences (MI)".

Menurut Sukardi (1988: 16), kecerdasan adalah kemampuan untuk menetapkan dan mempertahankan suatu tujuan, untuk mengadakan penyesuaian dalam rangka mencapai tujuan itu dan untuk bersikap kritis terhadap diri sendiri. Kecerdasan merupakan bakat tunggal yang dipergunakan dalam situasi menyelesaikan masalah apa pun. Seseorang yang tidak bisa memecahkan masalah atau persoalan semudahmudahnya juga memiliki inteligensi hanya tarafnya yang rendah.

Multiple Intelligences pada dasarnya merupakan pengembangan dari kecerdasan otak atau Intelegent Quotient (IQ), kecerdasan emotional atau Emotional Quotient (EQ), dan kecerdasan spiritual atau Spiritual Quotient (SQ). Nofianto (2008: 12) menyatakan bahwa ada 4 syarat khusus yang terdapat pada setiap kecerdasan yaitu setiap kecerdasan dapat dilambangkan, mempunyai riwayat perkembangan,rawan terhadap cacat akibat kerusakan atau cedera pada wilayah otak tertentu, dan mempunyai keadaan akhir berdasar nilai budaya.

Safaria (2015: 24) mendefiniskan $M I$ sebagai suatu kemampuan ganda untuk memecahkan masalah-masalah yang dihadapi dalam kehidupan. Multiple Intelligences (MI) merupakan sebuah teori tentang kecerdasan yang dicetuskan Dr. Howard Gardner, seorang tokoh pendidikan dan psikologi. Teori ini menunjukkan bahwa tidak ada kegiatan manusia yang hanya menggunakan satu kecerdasan, tetapi menggunakan seluruh kecerdasan yang ada pada manusia. Multiple Intelligences terdiri dari kecerdasan linguistik, kecerdasan logika-matematika, kecerdasan visualspasial, kecerdasan gerak tubuh, kecerdasan musikal, kecerdasan interpersonal, kecerdasan intrapersonal, kecerdasan naturalis (Jahja, 2011: 397-400). 
Teori kecerdasan majemuk menurut Jasmine (2007: 13) adalah validasi tertinggi gagasan bahwa perbedaan individu adalah penting. Pemakaiannya dalam pendidikan sangat tergantung pada pengenalan, pengakuan dan penghargaan terhadap setiap atau berbagai cara siswa belajar, di samping pengenalan, pengakuan dan penghargaan terhadap setiap minat masing-masing siswa. Teori kecerdasan majemuk bukan hanya mengakui perbedaan individual ini untuk tujuan-tujuan praktis, seperti pengajaran dan penilaian, tetapi juga menganggap serta menerimanya sebagai sesuatu yang normal, wajar, bahkan menarik dan sangat berharga.

Berdasarkan teori MI menurut Budiningsih (2012: 119), ada beberapa hal yang perlu diperhatikan dalam teori ini, yaitu: (1) setiap orang memiliki semua kecerdasan itu, (2) banyak orang dapat mengembangkan masing-masing kecerdasannya sampai ke tingkat yang optimal, (3) kecerdasan biasanya bekerja bersama-sama dengan cara yang unik, dan (4) ada banyak cara untuk menjadi cerdas.

Berbagai macam kecerdasan tersebut dimiliki masing-masing individu. Amstrong (2004: 2) menyatakan bahwa kecerdasan tersebut terdiri atas sembilan tingkat kecerdasan dan dikenal sebagai Multiple Intelligences (MI) yang meliputi: 1) kecerdasan linguistik, 2) kecerdasan matematis-logis, 3) kecerdasan spasial-visual, 4) kecerdasan kinestetis-jasmani, 5) kecerdasan musikal, 6) kecerdasan interpersonal, 7) kecerdasan intrapersonal, 8) kecerdasan naturalis, dan 9) eksistensial.

Setiap orang memiliki $M I$ dalam tingkatan yang berbeda. Oleh karena itu setiap guru hendaknya bisa memahami kecerdasan dan kemampuan setiap peserta didik dengan baik, hal ini dikarenakan keadaan peserta didik dalam kelas berbeda-beda dan memiliki tingkat kecerdasan yang berbeda. Hal ini sesuai dengan peran guru sebagai motivator, fasilitator, dan pengarah atau direktor. Menurut Sardiman (2001: 143), sebagai motivator seorang guru mampu meningkatkan dan mengembangkan kegiatan belajar peserta didik. Guru sebagai fasilitator memberikan fasilitas atau kemudahan dalam proses belajar mengajar. Guru sebagai pengarah harus dapat membimbing dan mengarahkan kegiatan belajar peserta didik sesuai dengan tujuan yang dicita-citakan.

Baharuddin (2007: 152) berpendapat bahwa guru sebagai pendidik perlu menggunakan metode-metode tertentu dalam proses pembelajaran agar kecerdasan peserta didik bisa berkembang secara optimal.Pembelajaran berbasis $M I$ ini merupakan suatu proses pembelajaran yang menekankan guru untuk mengajar sesuai dengan kecenderungan gaya belajar peserta didik, karena di dalam suatu ruangan kelas terdapat beberapa peserta didik yang masing-masing memiliki MI yang berbeda.

Berdasarkan hasil observasi yang penulis lakukan di SMAN 1 V Koto Kampung Dalam Padang Pariaman, masih ada guru yang kurang tepat dalam memilih strategi pembelajaran. Guru masih terfokus kepada satu metode pembelajaran tanpa adanya variasi dalam mengajar dan guru masih belum 
mengetahui apa itu $M I$. Hal ini menyebabkan peserta didik yang aktif dalam pembelajaran akan lebih cepat bosan dalam pembelajaran dan akhirnya peserta didik akan malas memperhatikan guru dalam menjelaskan pelajaran. Hal yang dialami peserta didik ini dapat menyebabkan hasil belajar yang diperoleh peserta didik tidak sesuai dengan yang diharapkan. Untuk mencegah kurang fokus dan kurang perhatiannya peserta didik terhadap guru dalam proses pembelajaran seharusnya guru mengetahui kondisi peserta didiknya yaitu salah satunya mengetahui tingkatan $M I$ yang ada pada peserta didik.

Multiple Intellegences peserta didik tidak bisa hanya dilihat dari nilai yang diperoleh, tetapi dari proses dan kemampuan peserta didik dalam menyelesaikan tiap masalah yang diberikan. Masing-masing peserta didik memiliki MI yang berbedabeda. Chatib (2015: 75) menyatakan bahwa tiap peserta didik berpotensi untuk mengembangkan tiap jenis kecerdasan. Kecerdasan ini terdiri atas kecerdasan linguistik, logis-matematis, spasial-visual, kinestis, musik, interpersonal, intrapersonal, eksistensialis, dan naturalistik.

Selaras (2014: 23) mengungkapkan bahwa tingkat kecerdasan tersebut tidak digunakan satu persatu, namun dapat digunakan pada suatu waktu secara bersamaan dan saling melengkapi satu sama lain. Seorang pendidik haruslah memperhatikan masing-masing kecerdasan yang dimiliki peserta didik agar potensi kecerdasan mereka dapat dikembangkan secara maksimal. Pada dasarnya tidak ada peserta didik yang bodoh, semua manusia memiliki sembilan tingkat kecerdasan itu namun, hanya beberapa kecerdasan saja yang menonjol dari dirinya. Hal ini dapat disebabkan dari potensi bawaan yang dimiliki seseorang atau potensi mana yang biasa diasah dari lingkungan sekitar mereka.

Banyak manfaat yang dapat diperoleh dengan mengetahui tingkatan $M I$ peserta didik, baik bagi sekolah, guru, dan juga peserta didik itu sendiri. Hasanah (2015: 230) menyatakan manfaat $M I$ bagi guru antara lain: memiliki special moment dan strategi-strategi mengajar yang bisa terkumpul dalam menyusun RPP, guru juga dapat memantau perkembangan peserta didik dan membantu mengembangkannya, dan juga guru dapat mengetahui kecenderungan kecerdasan peserta didik sehingga akan tercipta suasana pembelajaran yang menyenangkan. Bagi peserta didik itu sendiri: dapat menambah tingkat percaya diri peserta didik, selain itu peserta didik juga dapat mengukur tingkat kecerdasannya berdasarkan potensi $M I$ nya yang terus digali oleh guru, karena guru berperan sebagai motivator dan fasilitator.

Berdasarkan permasalahan berupa belum diketahuinya bagaimana tingkatan kecerdasan majemuk yang dimiliki peserta didik lintas minat biologi pada peminatan ilmu sosial dan ilmu bahasa. Karena itu perlu diketahui tingkatan kecerdasan tersebut agar guru bisa menentukan bagaimana strategi pembelajaran yang tepat digunakan untuk meningkatkan motivasi dan membantu mengembangkan kemampuan peserta didik. Penelitian ini bertujuan untuk mengungkap bagaimana tingkatan $M I$ peserta 
didik kelas X Peminatan Ilmu Sosial dan Ilmu Bahasa Lintas Minat Biologi di SMAN 1 V Koto Kampung Dalam.

\section{METODE PENELITIAN}

Penelitian ini adalah penelitian deskriptif. Populasi pada penelitian ini adalah peserta didik Kelas X yang terdaftarpadatahunpelajaran 2018/2019 peminatan ilmu sosial yang terdiri atas 3 kelas yang sudah homogen dan 1 kelas peserta didik peminatan ilmu bahasa. Sampel peserta didik peminatan ilmu sosial diambil menggunakan teknik simple random sampling dengan cara mengundi salah satu kelas pada populasi dan yang menjadi sampel adalah kelas X IS 3. Peserta didik ilmu bahasa sampel diambil menggunakan teknik total sampling.

Tingkatan $M I$ peserta didik didapatkan dengan menggunakan instrumen berupa angket yang dimodifikasi dari Selaras (2014: 84) yang telah valid. Angket $M I$ terdiri dari 74 butir pertanyaan untuk 9 tingkatan $M I$. Skala yang terdapat pada angket merupakan skala Likert yang sudah di modifikasi. Alternatif jawaban raguragu dihilangkan agar meminimalisir kesalahan peserta didik dalam mengisi angket. Teknik analisis data yang digunakan adalah teknik statistik deskriptif, menggunakan rumus presentase.

\section{HASIL PENELITIAN DAN PEMBAHASAN}

Data hasil penelitian Multiple Intelligences (MI) peserta didik diperoleh dengan menyebarkan angket kepada peserta didik kelas X yang dijadikan sampel penelitian yang terdiri dari 74 butir pernyataan. Rata-rata skor dari sebaran angket $M I$ peserta didik dideskripsikan pada Gambar 1.

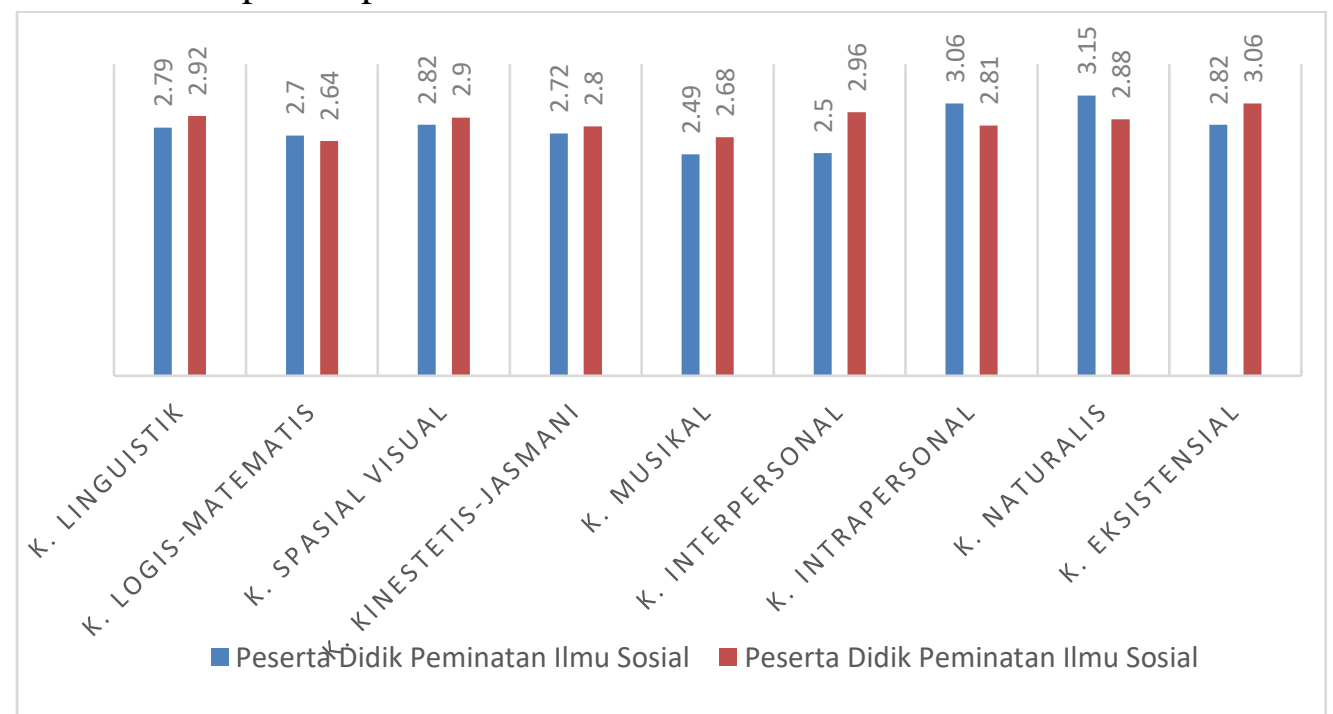

Gambar 1. Perbandingan Skor Multiple Intelligences Peserta Didik Kelas X Peminatan Ilmu Sosial dan Ilmu Bahasa Lintas Minat Biologi di SMAN 1 V Koto Kampung Dalam 
Berdasarkan hasil penyebaran angket $M I$ didapatkan rerata nilai kecerdasan yang dimiliki peserta didik kelas X lintas minat biologi SMAN 1 V Koto Kampung Dalam Padang Pariaman. Peserta didik Kelas X Peminatan Ilmu Bahasa memiliki tingkat kecerdasan yang dominan yaitu kecerdasan eksistensial, diikuti dengan kecerdasan interpersonal, kecerdasan linguistik, kecerdasan spasial-visual, kecerdasan naturalis, kecerdasan intrapersonal, kecerdasan kinestetis-jasmani, kecerdasan musikal, dan kecerdasan logis-matematis. Peserta didik Kelas X Peminatan Ilmu Sosial memiliki kecerdasan naturalis yang paling dominan diikuti kecerdasan intrapersonal, kecerdasan eksistensial, kecerdasan spasial-visual, kecerdasan linguistik, kecerdasan kinestetik-jasmani, kecerdasan interpersonal, dan kecerdasan musikalis.

Kecerdasan yang dimiliki peserta didik berbeda-beda antara satu dengan yang lainnya. Motivasi dan pengajaran dari guru berperan penting dalam keberhasilan pengembangan tiap kecerdasan peserta didik. Chatib (2015: 75) menyatakan bahwa tiap peserta didik berpotensi untuk mengembangkan tiap jenis kecerdasan. Suarca (2005: 86-87) menyatakan bahwa pengetahuan tentang MI pada peserta didik membantu untuk mengoptimalkan pemahaman terhadap peserta didik, sehingga guru dapat mengoptimalkan kecerdasan yang dominan pada peserta didik.

\section{Kecerdasan Linguistik}

Berdasarkan hasil analisis data didapatkan hasil rata-rata skor kecerdasan linguistik sebesar 2,79 pada peserta didik peminatan ilmu sosial dan 2,92 pada peserta didik peminatan ilmu bahasa. Artinya kecerdasan linguistik peserta didik ilmu bahasa lebih dominan dibandingkan peserta didik ilmu sosial. Hasil pengamatan peneliti juga diketahui bahwa guru biologi di sekolah SMAN 1 V Koto Kampung Dalam menggunakan metode diskusi kelompok. Guru juga menugaskan peserta didik untuk membuat rangkuman dari materi yang didiskusikan. Proses pembelajaran seperti ini dapat meningkatkan kecerdasan linguistik peserta didik. Hal ini sejalan dengan yang dikemukakan oleh Fatonah (2009: 239) bahwa kecerdasan linguistik dapat dikembangkan dengan cara menstimulasi peserta didik dengan membaca, seperti membaca buku IPA yang menarik. Nurindah (2010: 45) juga berpendapat bahwa peserta didik yang memiliki kecerdasan linguistik lebih cepat memahami materi pembelajaran melalui pendengaran, bahan bacaan, tulisan dan melalui diskusi atau debat, kemudian peserta didik dengan kecerdasan linguistik susah belajar dalam suasana yang ramai dan banyak gangguan dari luar.

\section{Kecerdasan Logis-Matematis}

Berdasarkan hasil analisisdidapatkan hasil rata-rata skor kecerdasan logismatematis sebesar 2,70 pada peserta didik peminatan ilmu sosial dan 2,64 pada peserta didik peminatan ilmu bahasa. Artinya kecerdasan logis-matematis peserta 
didik ilmu sosial lebih dominan dibandingkan peserta didik ilmu bahasa. Hasil ratarata skor kecerdasan logis-matematis tidak dominan dibandingkan kecerdasan lainnya karena pembelajaran biologi hanya terfokus di dalam kelas. Berdasarkan hasil wawancara dengan guru, peserta didik jarang melakukan eksperimen di luar kelas. Oleh karena itu, kecerdasan logis-matematisnya juga jarang dilatih. Padahal peserta didik dengan tingkat kecerdasan logis-matematis dominan akan memperlihatkan minat yang besar terhadap kegiatan eksplorasi. Nurindah (2010: 64) menyatakan bahwa peserta didik dengan kecerdasan logis-matematis lebih suka melakukan eksperimen dilaboratorium, mengkategorikan, menganalisa data dan susah dalam melakukan pembicaraan di depan banyak orang. Raharjo (2010: 321) menyatakan bahwa peserta didik dengan tingkat kecerdasan logis-matematis mengalami kesulitan jika dihadapkan pada rangkaian huruf, tetapi mudah terlibat angka dan senang berhitung. Peserta didik belajar melalui angka, berfikir logis, belajar melalui mengkategorikan, mengelompokkan, menandai persamaan dan perbedaan benda di sekelilingnya. Peserta didik belajar mencermati dan menandai ciri-ciri sesuatu. Amir (2013: 5) juga menyatakan bahwa kecerdasan ini memiliki ciri-ciri yaitu kepekaan pada pola hubungan logis, pernyataan dan dalil, fungsi logis dan abstraksi lainnya.

\section{Kecerdasan Spasial-Visual}

Berdasarkan hasil analisis data didapatkan hasil rata-rata skor kecerdasan spasial-visual sebesar 2,82 pada peserta didik peminatan ilmu sosial dan 2,90 pada peserta didik peminatan ilmu bahasa. Artinya kecerdasan spasial-visual peserta didik ilmu bahasa lebih dominan dibandingkan peserta didik ilmu sosial. Peserta didik dengan kecerdasan spasial-visual lebih tertarik belajar biologi jika guru menggunakan media dalam pembelajaran. Media pembelajaran dapat berupa torso, grafik, slide power pointdan charta. Hal ini dikarenakan peserta didik berasal dari peminatan ilmu sosial sehingga belajar dengan menggunakan media berupa charta dan grafik lebih menyenangkan daripada tidak menggunakan media tersebut. Guru di SMAN $1 \mathrm{~V}$ Koto Kampung Dalam dalam proses pembelajaran jarang sekali menggunakan media. Hal inilah yang menyebabkan proses pembelajaran kurang berjalan dengan baik.Nurindah (2010: 66) menyatakan bahwa peserta didik dengan kecerdasan spasial-visual senang belajar dengan menghafal dan menggambar, namun peserta didik dengan kecerdasan spasial-visual susah dalam menelaah kata-kata. Hal ini sejalan dengan penelitian yang telah dilakukan oleh Selaras (2013: 28) yang menyatakan bahwa proses pembelajaran peserta didik dengan kecerdasan spasialvisual contohnya dengan menggunakan media ajar yang menarik seperti: animasi, charta, alat peraga (objek-objek yang dapat diamati, baik dalam kedaan segar maupun awetan). Riandi (2013: 80) juga menyatakan dengan adanya media ajar akan menjadikan kegiatan belajar menjadi lebih menarik. 


\section{Kecerdasan Kinestetik-Jasmani}

Berdasarkan hasil analisis data didapatkan hasil rata-rata skor kecerdasan kinestetik-jasmani sebesar 2,72 pada peserta didik peminatan ilmu sosial dan 2,80 pada peserta didik peminatan ilmu bahasa. Artinya kecerdasan kinestetik-jasmani peserta didik ilmu bahasa lebih dominan dibandingkan peserta didik ilmu sosial. Peserta didik menyukai materi biologi karena guru sering mengadakan kegiatan praktikum dan mendemonstrasikan pelajaran di depan kelas. Namun berdasarkan pengamatan dan wawancara peneliti dengan guru diketahui bahwa guru jarang mengadakan kegiatan praktikum dan mendemonstrasikan pelajaran di depan kelas sehingga ini juga yang menyebabkan kecerdasan ini bukan yang paling dominan diantara yang lainnya. Hal ini sejalan dengan Suarca (2005: 88) yang menyatakan peserta didik dengan kecerdasan kinestetik-jasmani senang bergerak aktif saat pembelajaran dan suka menyentuh sesuatu yang ingin mereka pelajari. Selaras (2014: 28) juga menyatakan bahwa peserta didik senang melakukan hal yang dipraktikkan langsung. Pengaplikasian dalam proses pembelajaran misalnya, kegiatan praktikum dan penggunaan media pembelajaran yang melibatkan siswa dalam penggunaannya.

\section{Kecerdasan Musikal}

Berdasarkan hasil analisis data didapatkan hasil skor rata-rata kecerdasan musikal sebesar 2,49 pada peserta didik peminatan ilmu sosial dan 2,68 pada peserta didik peminatan ilmu bahasa. Artinya kecerdasan musical peserta didik ilmu bahasa lebih dominan dibandingkan peserta didik ilmu sosial. Rata-rata skor kecerdasan musikalpesertadidiktidak dominan karena guru tidak pernah menggunakan musik sebagai media pembelajaran biologi. Seharusnya dalam beberapa materi biologi, guru bisa memanfaatkan media yang berhubungan dengan musik agar peserta didik mampu untuk mengembangkan dan mengekspresikan kecerdasan musikalis yang dimilikinya. Gunawan (2006: 235) memandang kecerdasan musikalis sebagai kemampuan untuk menikmati, mengarang, membedakan, mengarang, membentuk, dan mengekpresikan bentuk-bentuk music. Fatonah (2009: 239) menyatakan bahwa guru dapat mengembangkan kecerdasan musikal peserta didik dengan melatih kepekaan terhadap suara yang terdapat dilingkungan. Pada saat pembelajaran mendengarkan musik membuat situasi lebih menyenangkan. Menurut Selaras (2014: 28), peserta didik dengan kecerdasan musikalis cenderung lebih tertarik dengan proses pembelajaran dengan memutar music atau mengganti lirik lagu dengan poinpoin pembelajaranyang sulit diingat dan dipahami oleh peserta didik.

\section{Kecerdasan Interpersonal}

Berdasarkan hasil analisis didapatkan hasil rata-rata skor kecerdasan interpersonal sebesar 2,50 pada peserta didik peminatan ilmu sosial dan 2,96 pada 
peserta didik peminatan ilmu bahasa. Artinya kecerdasan interpersonal peserta didik ilmu bahasa jauh lebih dominan dibandingkan peserta didik ilmu sosial. Metode yang digunakan guru dalam pembelajaran biologi adalah metode diskusi kelompok. Tiap kelompok membahas tentang materi yang berbeda-beda. Di dalam kelompok, peserta didik berinteraksi dengan peserta didik lainnya. Rofiah (2016: 75) menyatakan bahwa peserta didik dengan kecerdasan interpersonal akan mudah berkomunikasi dan berhubungan dengan orang lain. Peserta didik akan lebih menyukai kegiatan berkelompok. Gunawan (2014: 240) menjelaskan kecerdasan interpersonal sebagai kemampuan untuk masuk ke dalam diri orang lain, mengerti dunia, pandangan, sikap kepribadian dan karakater orang lain. Selaras (2014: 29) juga menyatakan bahwa pembelajaran dengan berkelompok dapat mengajarkan peserta didik memberi dan menerima umpan balik dan dapat membandingkan informasi antar peserta didik.

\section{Kecerdasan Intrapersonal}

Berdasarkan hasil analisis didapatkan hasil rata-rata skor kecerdasan interpersonal sebesar 3,06 pada peserta didik peminatan ilmu sosial dan 2,81 pada peserta didik ilmu bahasa. Artinya kecerdasan intrapersonal peserta didik ilmu sosial lebih dominan dibandingkan peserta didik ilmu bahasa. Peserta didik yang memiliki kecerdasan intrapersonal dominan mampu memahami diri sendiri dan mampu mengendalikan diri dalam situasi konflik. Hal ini terlihat saat penulis memberikan beberapa pertanyaan saat wawancara. Kecerdasan intrapersonal membantu peserta didik mengenali diri dan batasan dirinya sehingga dapat mengekspresikan diri dengan baik. Suparno (2004: 41) menjelaskan kecerdasan intrapersonal sebagai kemampuan yang berkaitan dengan pengetahuan akan diri sendiri dan kemampuan untuk secara tepat dan nyata menciptakan gambaran tentang diri sendiri. Fatonah (2009: 241) menyatakan bahwa pengembangan kecerdasan intrapersonal dapat denagn belajar menerima diri sendiri, baik kelemahan dan kelebihan yang ada pada diri sendiri. Hal ini juga sejalan dengan pernyataan Selaras (2014: 29) yaitu peserta didik dengan kecerdasan intrapersonal pada proses pembelajaran suka dengan pemberian penghargaan sehingga peserta didik menjadi termotivasi.

\section{Kecerdasan Naturalis}

Berdasarkan hasil analisis didapatkan rata-rata skor kecerdasan naturalis sebesar 3,15 pada peserta didik peminatan ilmu sosial dan 2,88 pada peserta didik peminatan ilmu bahasa. Artinya kecerdasan naturalis peserta didik ilmu sosial lebih dominandibandingkanpesertadidikilmubahasa. Pada peserta didik peminatan sosial, kecerdasan naturalis inilah yang paling dominan diantara yang lainnya. Pada peserta didik peminatan ilmu bahasa kecerdasan ini merupakan kecerdasan kelima yang paling menonjol diantara yang lainnya. Peserta didik yang memiliki kecerdasan naturalistik dominan memiliki kemampuan untuk membedakan berbagai varietas 
tanaman, dan hewan. Peserta didik dapat mengerti flora dan fauna dengan baik. Peserta didik merasa tertarik saat guru berbicara mengenai fenomena alam, seperti asal usul binatang pertumbuhan tanaman, tata surya, dll. Ege (2016: 871) dan Amstrong (2003: 23) menyatakan bahwa kecerdasan naturalistik adalah kemampuan dalam melakukan kategorisasi dan membuat hierarki terhadap keadaan organisme seperti tumbuh-tumbuhan, binatang, dan alam serta memiliki kemampuan mengenali bentuk yang ada disekitarnya. Selaras (2014: 29-30) juga menyatakan bahwa peserta didik dengan kecerdasan naturalistik lebih senang belajar melalui aktivitas di luar kelas, berwisata kea lam bebas, aktivitas fisik lainnya, dan peka terhadap lingkungan sekitar.

\section{Kecerdasan Eksistensial}

Berdasarkan hasil analisis didapatkan hasil rata-rata skor kecerdasan eksistensial sebesar 2,82 pada peserta didik peminatan ilmu sosial dan 3,06 pada peserta didik peminatan ilmu bahasa. Artinya kecerdasan eksistensial peserta didik ilmu bahasa lebih dominan dibandingkan peserta didik ilmu sosial. Pada peserta didik peminatan ilmu bahasa, kecerdasan eksistensial ini adalah kecerdasan yang paling dominan diantara kecerdasan lainnya. Pada peserta didik peminatan ilmu sosial, kecerdasan ini adalah kecerdasan keempat paling memonjol diantara kecerdasan lainnya. Peserta didik dengan kecerdasan eksistensial mampu melihat hal yang tidak terpikirkan oleh orang lain seperti asal usul tumbuhan dan hal yang terjadi setelah tumbuhan mati. Peserta didik yang memiliki kecerdasan eksistensial dominan cendrung bersikap mempertanyakan segala sesuatu yang jarang dipertanyakan oleh peserta didik lain. Hal ini dapat terlihat saat guru memberikan pernyataan tentang sesuatu, peserta didik yang memiliki kecerdasan eksistensial yang dominan akan selalu kritis menanggapi dan bertanya mengenai pernyataan tersebut. Fatonah (2009: 242) menyatakan bahwa peserta didik yang memiliki kecerdasan eksistensial akan bertanya-tanya kedirinya dan makhluk hidup lainnya. Wahyudi (2011: 66) juga berpendapat bahwa peserta didik denga kecerdasan eksistensial yang kuat senang mencari, mensintesis ide-ide dan senang bertanya-tanya tentang keberadaan atau pertanyaan tentang seluk beluk keberadaan.

\section{PENUTUP}

Tingkat $M I$ yang dimiliki oleh peserta didik kelas $\mathrm{X}$ peminatan ilmu sosial lintas minat biologi di SMAN 1 V Koto Kampung Dalam berbeda-beda. Berdasarkan hasil rata-rata skor $M I$ terlihat bahwa kecerdasan naturalis yang paling dominan diantara kecerdasan yang lainnya. Kecerdasan dominan berikutnya adalah kecerdasan intrapersonal, kecerdasan eksistensial, dan kecerdasan spasialvisual.Tingkat $M I$ yang dimiliki oleh peserta didik kelas $\mathrm{X}$ peminatan ilmu bahasa lintas minat biologi SMAN $1 \mathrm{~V}$ Koto Kampung Dalam Padang Pariaman juga 
berbeda-beda. Berdasarkan hasil rata-rata skor $M I$ terlihat bahwa kecerdasan eksistensial yang paling dominan diantara kecerdasan yang lainnya. Kecerdasan dominan berikutnya adalah kecerdasan interpersonal, kecerdasan linguistik dan kecerdasan spasial-visual.

\section{REFERENSI}

Ahsan, M., Purnomo B. S., Harry S. D. 2015. Multiple Intelligence MenentukanJurusan di SMA MenggunakanTeknikMulti-Attribute Decision Making. Jurnal EECCIS, Vol. 9, No. 1: 25-30.

Amir, A. 2013. "Pembelajaran Matematika dengan Menggunakan Kecerdasan Majemuk (Multipke Intelligences)”. Logaritma, Vol. 1, No. 1: 1-14.

Amstrong, T. 2004. Kamu lebih Cerdas daripada yang Kamu Duga. Batam: Interaksara.

Baharudin dan Wahyuni, N. 2007. Teori Belajar dan Pembelajaran. Yogyakarta: Arruzz Media

Budiningsih, A. 2012. Belajar dan Pembelajaran. Jakarta: Rineka Cipta.

Chatib, M. 2015. Sekolahnya Manusia Sekolah Berbasis Multiple Intelligences di Indonesia. Bandung: Kaifa.

Ege, B. 2016. "Hubungan antara Multiple Intelligences dengan Hasil Belajar Kognitif Siswa pada Mata Pelajaran Ilmu Pengetahuan Alam". Prosiding Semnas Pendidikan IPA Pascasarjana, Vol. 1, No. 1: 863-872.

Fatonah, S. 2009. "Menumbuhkan Kecerdasan Majemuk Anak Dengan Mengenal Gaya Belajarnya Dalam Pembelajaran IPA SD”. Al-Bidayah, Vol.1, No. 2: 229-245.

Gunawan, A. 2006. Petunjuk Praktis untuk Mencerdaskan Accelerated Learning. Jakara: Gramedia Pustaka Umum.

Hasanah, U. 2015. "Konsep Pembelajaran Berbasis Multiple Intelligences dalam Perspektif Munif Chatib”. Jurnal Tarbawiyah, Vol. 12, No. 3: 209-232.

Jasmine, J. 2007. Panduan Praktis Mengajar Berbasis Kecerdasan Majemuk. Bandung: Nuansa.

Nofianto, S. 2008. The Golden Teacher. Depok: Lingkar Pena Kreativa. 
Nurindah, L. 2010. "Pengaruh Multiple Intelligences terhadap Hasil Belajar Siswa pada Mata Pelajaran Bahasa Jepang di SMAN 13 Bandung”. Skripsi. Bandung: Universitas Pendidikan Indonesia.

Prawira, P. A. 2012. Psikologi Pendidikan dalam Perspektif Baru. Jogjakarta: ArRuzz Media.

Raharjo, A. 2010. "Hubungan Antara Multiple Intelligence dengan Prestasi Belajar Siswa Kelas XI di SMA Negeri 10 Malang”. Jurnal Psikologi, Vol. 2, No. 2: 311-322.

Riandi. 2013. "Media Pembelajaran biologi". Online. http://file.upi.edu/Direktori/FPMIPA/JUR._PEND._BIOLOGI/19630501198803RIANDI/Bahan_Kuliah/ Media_pembelajaran_biologi.pdf, diunduh Tanggal 20 April 2019.

Rofiah, N. H. 2016. "Menerapkan Multiple Intelligences dalam Pembelajaran di Sekolah Dasar". Jurnal Dinamika Pendidikan Dasar, Vol.8, No. 1: 68-79.

Safaria, T. 2005. Interpersonal Intelligences Metode Pengembangan Kecerdasan Interpersonal Anak. Yogyakarta: Amara Books.

Sardiman, A.M. 2001. Interaksi dan Motivasi Belajar Mengajar. Jakarta: RajagrafindoPersada.

Selaras, G. H. 2014. "Hubungan Multiple Intelligences dengan Hasil Belajar Biologi Siswa Kelas X SMAN di Kota Padang”. E-Journal UNP, Vol. 1, No. 1: 22-34.

Suarca, K. 2005. “Kecerdasan Majemuk pada Anak”. Sari Pediatric, Vol.7, No. 2: $85-92$.

Sudjana, N. 2005. Metoda Statistika. Bandung: Tarsito.

Sukardi, D. K. 1988. Analisis Tes Psikologis. Denpasar: Rineka Cipta.

Suparno, P. 2004. Teori Intelegensi Ganda dan Aplikasinya di Sekolah. Yogyakarta: Gramedia Pustaka Utama.

Wahyudi, D. 2011. "Pembelajaran IPS Berbasis Kecerdasan Interpersonal, Intrapersonal, dan Eksistensial". Jurnal UPI Edu, Vol 1, No. 1: 33-45. 